\title{
Impact of Technology in Classrooms of Saudi Arabian Students in a Midwest University
}

\author{
Saeed Nasser saeed Alqahtani* \\ Educational Administration, King Saudi University, Riyadh Saudi Arab \\ *Corresponding author: Alqahtanis@findlay.edu
}

Received September 03, 2019; Revised October 15, 2019; Accepted November 14, 2019

\begin{abstract}
This study is aimed at identifying the impact of technology in the classrooms for Saudi students at Midwestern University. To achieve this goal, the researcher conducted a survey on a group of graduate students in Saudi Arabia who are studying in small universities in the Midwest in the United States. The survey inquiries from students, the type of technology used in their studies in Saudi Arabia, how they helped them teach, and how technology changed from their university level in Saudi Arabia to their graduate level in the United States. The study reached the following main results: - The use of technology in the educational process is very useful if used well, as the student. - This type of study can help educators understand the effects of different factors on student preference for learning devices. Although this study contained some limitations, the overall outcome of this research study was conclusive. Limitations of this study included the absence of a definition of income. The study was conducted only in small universities in the Midwest, where the study was completed only once, and the study was not concluded over a period.
\end{abstract}

Keywords: impact, technology, classrooms

Cite This Article: Saeed Nasser saeed Alqahtani, "Impact of Technology in Classrooms of Saudi Arabian Students in a Midwest University.” American Journal of Educational Research, vol. 7, no. 11 (2019): 810-817. doi: 10.12691/education-7-11-9.

\section{Introduction}

It has been said that knowledge is power, and rightfully so. Knowledge is what empowers and drives modern society. It is what allows people to continue to advance and evolve over time. It is what teaches people the difference between right and wrong and what prevents society from making the same mistakes of the past. Without education, society would be in a constant state of standstill, with no progress in any direction.

There are many variations of education, each one contributing to society in some way. It can be argued that some primitive and third world societies survive without structured education, and that is true for societies that have no business structure or international dependence. Furthermore, these societies can function quite well and be happy doing so, even when they do not have a monetary system, such as the case of the Piraha society in South America (New Yorker). However, for the majority of societies that rely on a business structure for measured success, education is not only necessary, it is imperative. Without education, development and progress is not possible.

Some aspects of education are more beneficial to society than others. There have been many contributions to the betterment of education in society throughout history. The printing press, for example, was one of the most beneficial contributions to education in history. Likewise, the scientific breakthrough of technology has contributed immensely to the much more recent success and advancements of education. It has created a pathway for students to have access to endless means of knowledge and information, it has enhanced learning, and it has changed the face of education permanently.

The implementation of technology in the classroom has allowed students to have a tremendous advantage over those of previous years. During the past 20 years, technology has made a tremendous difference in the way that college students in the United States learn. With the continuation of advancements in technology, the students of the future will be essentially limitless.

\subsection{Significance of Problem or Issue}

For education to continue to advance, technology must be interwoven into every aspect of it. There are a number of educators that would cringe at the idea of using technology in the classroom. They would argue that devices such as cell phones and iPads have no pedagogical value and only serve as a disruption and a distraction. However, statistical data may demonstrate that the free use of technology in the classroom serves as an educational catalyst. 


\subsection{Context}

I will be conducting a survey on a group of Saudi Arabian graduate students studying in the United States. The survey will question the type of technology that they used in their undergraduate studies in Saudi Arabia. It will ask how it helped them in their education and how technology has changed from their undergraduate level in Saudi Arabia and their graduate level in the United States. The group of students will consist of male and female students at the graduate level of education in a small Midwestern university.

\subsection{Hypothesis (a statement)}

If Saudi students are given the opportunity to use advanced educational technologies in their classes, then their perceptions of the quality of education they receive and their ability to obtain knowledge will increase as compared to previous education with older, less advanced educational technologies.

\subsection{Independent Variable}

The independent variable is advanced educational technologies such as ipads and laptops in their classes

\subsection{Dependent Variable}

The dependent variable for this study will be their perceptions of the quality of education students receive and the students' ability to obtain increased knowledge overall.

\section{Review of Literature}

Many people benefit from the use of technology in their personal lives. This statement is even truer for those who not only use it in their personal lives, but who also use it in their academic lives. Those who do this stand to benefit in a way that was never possible before the implementation of technology in education. This study will show the many advantages of using technology in education and how it has come to play a vital role in educating the students of today and tomorrow.

\subsection{Benefits}

Technology is well known for the benefits that it brings to anyone who uses it. Education is no exception to this rule, enjoying a multitude of advancements by means of the utilization of technology in education. According to Bhat, technology is being used in every field in the world and has made great improvements to the teaching and learning process [1]. Technology brings many benefits to the field of education. Bhat states that some of those benefits are that technology improves the development of learning capabilities, it simplifies information gathering, it increases learning efficiency, it improves the students' motivation, it benefits students with special needs, it helps people pick up on skills through visual examples of what they need to do. It prepares students for the future, it increases knowledge and opportunities, and it is a catalyst for change [1]. This information era is present and every area in the world is being influenced by technology, especially education.

Technology's role has been vital in the enhancement of the learning process for students. Not only does it enhance learning for students, but technology also assists teachers with being able to communicate with students in an efficient and easy way. Computers and software programs that are the source of learning materials have allowed technology to make incredible changes to education [1]. These changes have improved the way educators teach students all over the world.

Research has shown that the use of technology can improve retention. Hew \& Cheung conducted a study that examined whether the use of podcast as compared to the use of a lecture would have an improvement on the student's ability to retain more of the lesson. They concluded that the students who used the podcast scored significantly higher on a subsequent exam than those who only learned by a lecture [2].

\subsection{Familiarity}

Lewis, Fretwell, Ryan, and Parham said that the effectiveness of an instructor depends heavily on the student's ability to understand the concepts that are being taught to them [3]. Because technology is already in the hands of many students and is even something that many students rely on for their day to day communication, the incorporation of technology into the classroom has been a welcome change and one that ensures that students will indeed have a better chance of understanding what is being taught to them. Most students are already comfortable with technology and familiar with it. The best method of learning for most students is through their own discovery. The use of multimedia in the classroom allows students to achieve a much higher percentage of learning than when they do not use multimedia in the classroom. It acts as a catalyst and a stimulant for the learning and teaching process to become more effective. For this reason, teaching through multimedia has started to replace more traditional teaching methods [4].

There is a reason that the use of technology in the classroom is becoming so widespread throughout the United States and many other countries. Universities have recognized this learning tool as being highly effective. Therefore, a great number of universities have adopted this method of teaching, if not as the sole medium of instruction, then at least as an addition and an equal to the traditional teaching methods. In fact, many colleges are eager to evolve to the new environment that technology brings them and have started to offer many courses in web-based formats and other formats that differ from the traditional formats [5].

Despite common belief that younger generations of people have been brought up on technology and therefore are quite familiar with it through daily exposure, Shaltry, Henriksen, Wu, and Dickson state that this belief might actually be less accurate than people understand. In fact, research has shown that students who are known as digital natives because of being raised with common use of technology do not necessarily have as fluid of skills with technology as have often been ascribed to their generation. 
Still, with basic coursework intended to change this shortcoming, students can become technologically competent very quickly and make full use of the technology available to them [6].

\subsection{Interest}

One of the biggest reasons that technology in education is so successful is that technology in and of itself is widely popular. In fact, it is something that touches the life of nearly every person in the United States. One study reported that between $85 \%$ and $99 \%$ of college students use Facebook [7]. These statistics mean that each of these students is familiar enough with technology to be able to access and actively maintain a social networking site. According to a survey conducted by Little-Wiles and Naimi, when the students who participated in the study were asked about whether they felt that having access to their grades online was important, $62 \%$ of those students said that it was extremely important while $25 \%$ of the students reported access to their grades online as very important [8]. Furthermore, Okoro emphasizes that social networking and other forms of electronic communication are highly efficient tools that can be used for teaching and that these tools have shown progressive improvement to the quality of learning outcomes of students of higher education recently [9].

Technology being incorporated in the classroom has many mediums. Blackboard, for example, is one method that many universities are beginning to prefer to utilize in order to allow their students to collaborate and learn online. According to Bradford, Porciello, Balkon, and Backus [10], it allows students to learn through a method in which instructors can easily meet their needs. It also allows instructors to use various teaching strategies such as lecture notes, audio recordings, and many other methods. Furthermore, it gives students a way to learn in which they find interesting and useful. When students are provided with learning materials that they are interested in using, it is much more likely to keep them involved in learning in the classroom. It not only keeps them engaged in active participation in their lessons but it gives them motivation to improve as well [11]. So it stands to reason that by engaging students in learning through technology, it allows the students to learn more effectively.

It is important to note that because of the incorporation of technology in education, students are more interested in their work than they were when they had no alternative to traditional teaching methods. Through the use of the medium of technology, inspiring and motivating students is a possibility with the use of communication tools. It is for this reason that the pedagogical approach is simplified without taking away from the depth of its original form. Consequently, the students are able to learn at their maximum potential when they integrate technology into their curriculums [12].

The growth of electronic learning is astonishing. Institutions are being forced to examine methods of cost effective and time efficiency such as computer labs, webinars, and more. The advancement of the field of technology and electronic learning is at an inconceivable level [13].

\subsection{Accessibility}

Technology can be found in nearly every home and classroom. It comes in many shapes and sizes and can range from being very simple and easy to use to being extremely complicated. Technologies such as mobile phones and tablet computers have the potential to change the fundamental ways that students learn and that teaching is carried out [12]. Jain states that technological devices such as laptops, the Internet, personal digital assistants, cameras and cell phones have all become so affordable and accessible that they have become integrated in society in sections all over the world [14].

The vitality of technology to the success of the future is so great that industrialized nations have invested millions of dollars to make technology accessible to those who have no other means of accessing them. People have donated technology, created foundations dedicated to the disbursement of technology, and even government organizations have been erected in the interest of spreading technology all over the world. There are even organizations such as "one laptop per child” dedicated to extending the benefits of technology to the poorest nations and schools. By doing this, students will be much more likely to be able to think at higher levels [15].

Through the use of technology, classes and everything required to complete them become incredibly accessible at the convenience of the student. Students can do everything online from applying for college and choosing their classes to reading their text books, performing research, and completing and submitting their assignments. Additionally, students can access their grades, contact their instructors and other students through email, and manage their accounts because of the advantages that technology brings [16].

\subsection{Counterargument}

It is difficult to dispute the fact that technology has allowed education to advance in ways that it never has before. However, with the benefits that technology brings education, there are also detriments that come with it. One of the major detriments of the use of technology in education is the increased opportunity for academic dishonesty. According to a study conducted by Ravasco, among the many different ways for students to cheat through the use of technology identity impersonation, substitution, and proxy attendance are the most frequently utilized [17]. These types of academic dishonesty are just some of the methods in which that verifying the identity of the person attending the classes is difficult, so teachers cannot hold the students accountable for them.

Furthermore, technology allows students to easily seek people who are willing to do their work for them. According to the book The Shadow Scholar, people who are willing to do homework assignments for others are in high demand. There are legitimate businesses composed of people who sell their services of completing homework for their clients. These businesses can be easily discovered through a simple inquiry on a search engine and they even pay taxes. ([18], p. 95) So, through the use of technology, academic dishonesty can potentially become easier for students to partake in. 
Another opposing opinion given against the benefits of technology argues that it doesn't have as great of a benefit as people believe it does. According to Russel [19], when studying distance learning, some researchers have concluded that there is little to no significance in the difference of outcomes between those who utilize technology to support their education and those who do not (as cited in Buche, [20]). Russel [19] also argues that computer technology in the education system has a minimal effect on learning, offering only the most disciplined and motivated learners any kind of positive outcome (author name, year as cited in Buche, [20]). Research that has these kinds of outcomes can cause people to believe that technology is not as beneficial as it appears to be.

\subsection{Summary}

The evidence presented in these studies has made a strong case for the benefits that technology has and potentially can bring to the field of education. Most researchers agree that there are tremendous benefits that both students and faculty can attain such as the increase of interest of studies by the students, the ease of access and use of technology, and the familiarity that most people already have with technology before applying it to their studies. Despite all of the research that has suggested that technology has incredible benefits to education, there are still some researchers that have come do a different conclusion, stating that the benefits of technology are miniscule. However, this opinion is the minority. The fact remains that technology has changed the way people learn for the better and, with continued advancements in technology, education will continue to advance as well.

\section{Design}

\subsection{Participants: Descriptions of the Sample \& Setting}

The students that will be used in this experiment will be students that are native to Saudi Arabia and have been studying in the United States. The students are college level students studying for their master's degree. The students each have a different background in terms of gender, age, marital status, and education. The students also have various majors. This study takes into consideration that some students are currently enrolled in classes that are online, while others are enrolled in classes that are live. Several of the students have classes both online and in the class room. The research tool that will be used for this study is a questionnaire. The questionnaire will have ten questions that will help the researcher to understand the student's background, previous exposure to technology, and current exposure to technology.

\subsection{Explanation of Procedures}

The data for this research will be recorded from the students on their own time. The questionnaire will be given to the students in paper form or by email and then they will be asked to fill out the questionnaire on their own time. They will then be asked to return the questionnaire within a two week time period. The data will subsequently be collected and be analyzed either in support of or contrary to the hypothesis of this study.

\subsection{Internal Validity Considerations}

Factors that could threaten the validity of the research could be the student's exposure to technology in their personal lives. The questionnaire will strictly be about the exposure of the students in their academic career, and it will not take into consideration the collective use of technology in each student's life. Because of the possible technology exposure in their personal lives, the students might not be able to accurately judge the improvement to their academic career as a result of the use of technology. Additionally, the number of students participating in the study could limit the validity of the results. Furthermore, the students who participate in this study will all be attending the same university, which means that their use of technology in the classroom will not have any varying degree.

\subsection{Plan for Data Analysis}

The data that is acquired through the medium of questionnaire will be collected through the use of either paper questionnaire or one that is transferred through electronic mail. The materials used are: computers, cell phones, televisions, Power Point, and videos. The factors such as the ages of the students and their backgrounds and personal uses of technology might have an effect on the way they answer the questionnaire.

\subsection{Time Line}

\begin{tabular}{|l|l|}
\hline Time & \\
\hline $\begin{array}{l}\text { September } \mathbf{2 5}^{\text {th }}, \mathbf{2 0 1 2} \\
\text { design the questionnaires }\end{array}$ & $\begin{array}{l}\text { The questionnaires will be created to } \\
\text { collect simple, easily understandable } \\
\text { information that is accurate and precise }\end{array}$ \\
\hline $\begin{array}{l}\text { October 1st }, \mathbf{2 0 1 3} \\
\text { Distribute Questionnaires }\end{array}$ & $\begin{array}{l}\text { The questionnaires will be distributed to } \\
\text { the students via paper questionnaires } \\
\text { and emails }\end{array}$ \\
\hline $\begin{array}{l}\text { October } \mathbf{1 5}^{\text {th }}, \mathbf{2 0 1 3} \\
\text { Qeadline for Returning }\end{array}$ & $\begin{array}{l}\text { The students will return the } \\
\text { questionnaires and the researcher will } \\
\text { collect them }\end{array}$ \\
\hline $\begin{array}{l}\text { October 22 } \\
\text { Data }\end{array}$ & $\mathbf{2 0 1 3}$ \\
\hline $\begin{array}{l}\text { Novemalysis } \\
\text { Research Paper Written with } \\
\text { Study Results }\end{array}$ & $\begin{array}{l}\text { The data from the collected } \\
\text { questionnaires will be analyzed } \\
\text { incorporated into the research paper }\end{array}$ \\
\hline
\end{tabular}

\section{Technology in Education}

1. What best describes you?

Marital Status:

Working:

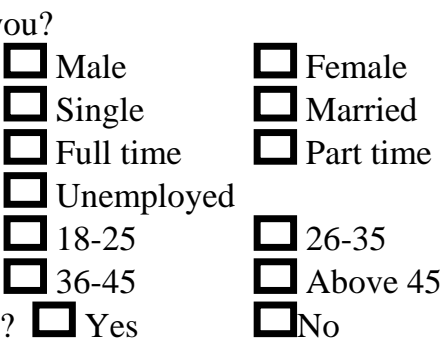

Age:

2. Do you have children? $\square$ Yes
3. What type of classes are you taking? No 
$\square$ Face-to-Face $\square$ Online

4. What level of course are you taking?

$\square$ Undergraduate $\square$ Graduate

5 . What is your specialization or major?

6. Which electronic materials are used in your current classes? (You can choose more than one)
$\square$ Computer
$\square$ Videos
$\square$ Power Point
$\square$ Internet links
$\square$ Smart Boards
DBlackboard
$\square$ handheld devices
$\square$ Other

7. How satisfied are you with the use of technology in your classroom?
$\square$ Very dissatisfied
$\square$ Somewhat dissatisfied
$\square$ Neutral
$\square$ Somewhat satisfied

8. Which electronic materials do you find most helpful in your current classes? (You can choose more than one)
$\square$ Computer
$\square$ Videos
$\square$ Power Point
Internet links
$\square$ Smart Boards
$\square$ Blackboard
$\square$ Handheld devices
$\square$ Other

9. What materials did you use in your classroom prior to coming to the United States?
$\square$ Computer
$\square$ Power Point
$\square$ Videos
$\square$ Internet links
$\square$ Other
$\square$ Blackboard

10. Considering your education prior to the use of technology in classrooms as compared to your current education with the use of technology, indicate how you feel your educational experiences have been impacted:

$\square$ No Improvement $\square_{\text {A little improvement }}$

$\square$ Very good improvement

Excellent improvement

\section{Reporting Data and Results}

There were no complications when collecting the data for this research paper. Each of the students was given a survey to take at their own convenience (See Appendix A). Some were given the survey in person, while other students received their surveys via email. They were asked to answer each question as honestly as possible. All of the students completed their surveys in a timely manner and returned them within an adequate time frame. The surveys had ten questions each which evaluated the personal exposure and experience of the students to technology. Questions 1, 2, 4, and 5 are questions relating to demographics: gender, their marital status, employment status, age range, whether the student has children, whether they are a graduate or undergraduate and their major or specialization. Questions 3, 6, 8, 9, and 10 inquired about their experience with technology: whether they are taking live or face-to-face classes, electronic materials currently used in their classes, and materials used in their previous studies in Saudi Arabia. Question 7 investigates the satisfaction of the students with the technology that is used in their classroom. Finally, question 10 asked the student to consider their prior education and their used of technology in classrooms as compared to their current education and use of technology and asked how their education has been impacted.

A total of fifty students completed this study. Of those fifty students, thirty-nine of them were male while eleven of them were female. All of the students who participated in this study originated from Saudi Arabia and were in the United States for the purpose of completing their education. Thirty-four of the students were married, and sixteen of the students were single. Only three of the students were employed part time, while forty-seven of the students were unemployed. Thirty-three of the students reported having children, and seventeen of the students did not have children. The amount of students who reported taking face to face classes was forty-four, and the amount of students who reported taking online classes was only six. Of the fifty students who participated in this study, twenty-eight of those students were graduate students and twenty-two students were undergraduate students. They reported various majors including Education, Leadership, Early Childhood Education, Environmental Studies, TESOL, and MBA.

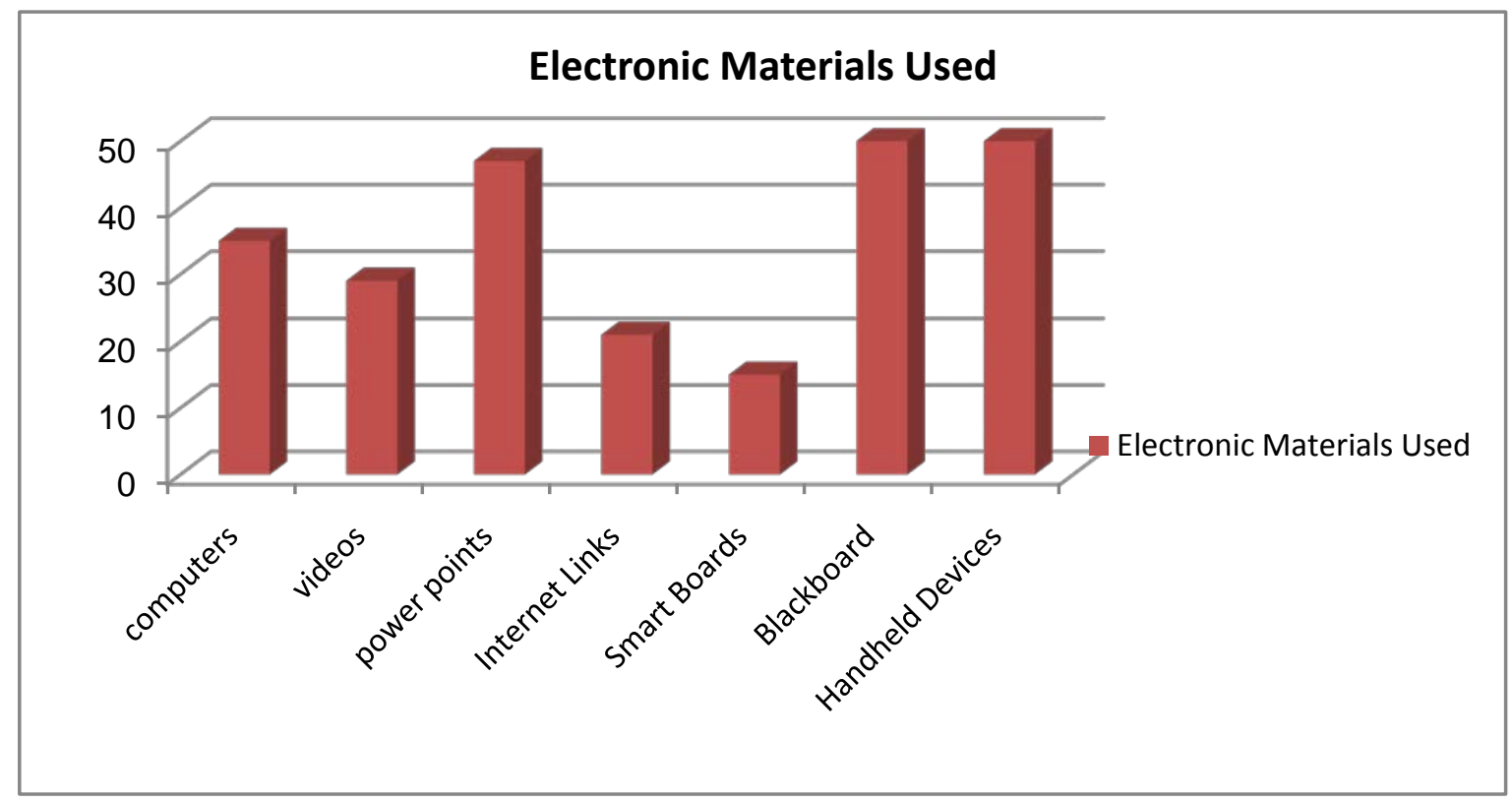

Figure 1. Electronic Materials Used 


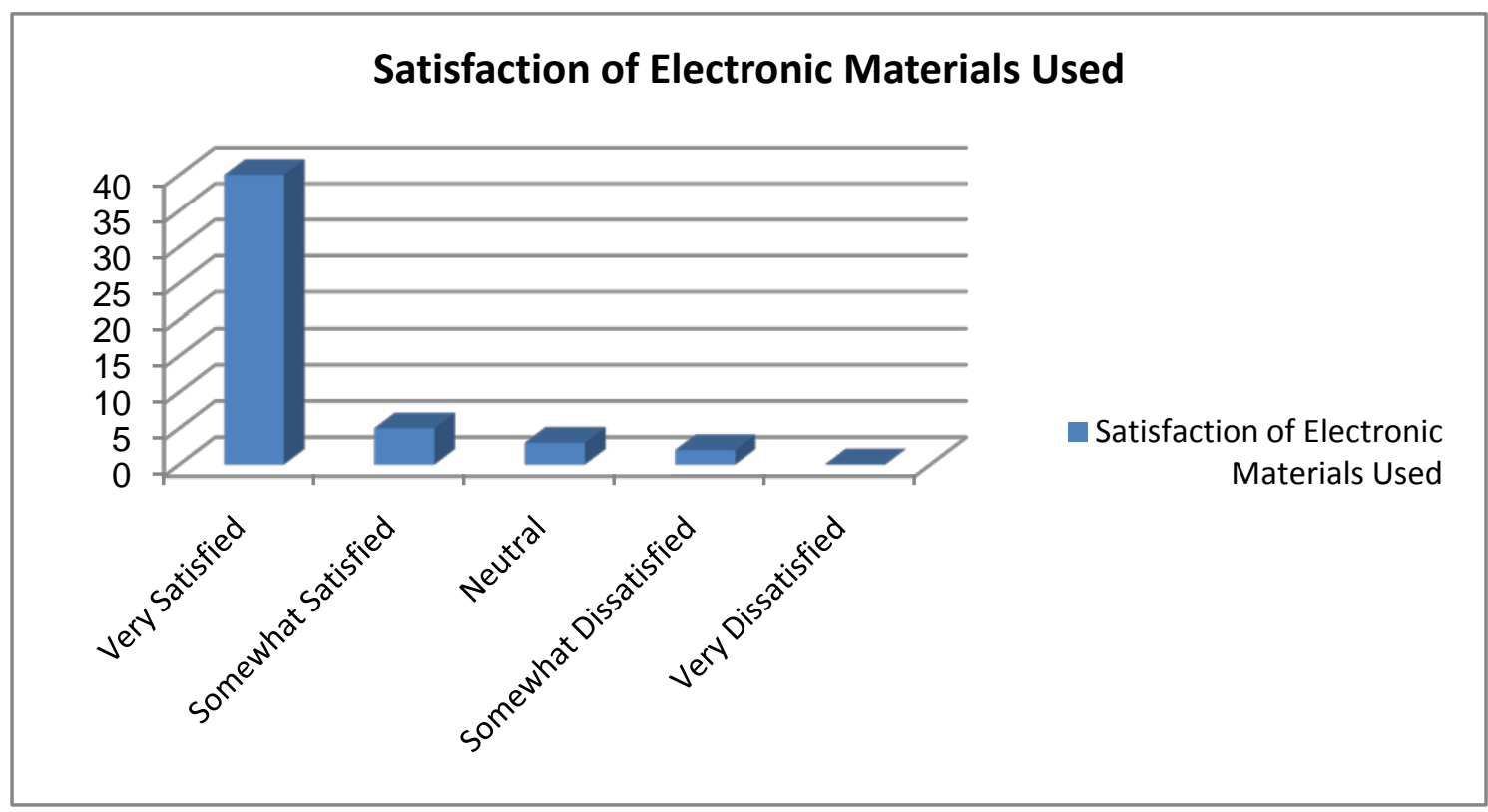

Figure 2. Satisfaction of Electronic Materials Used

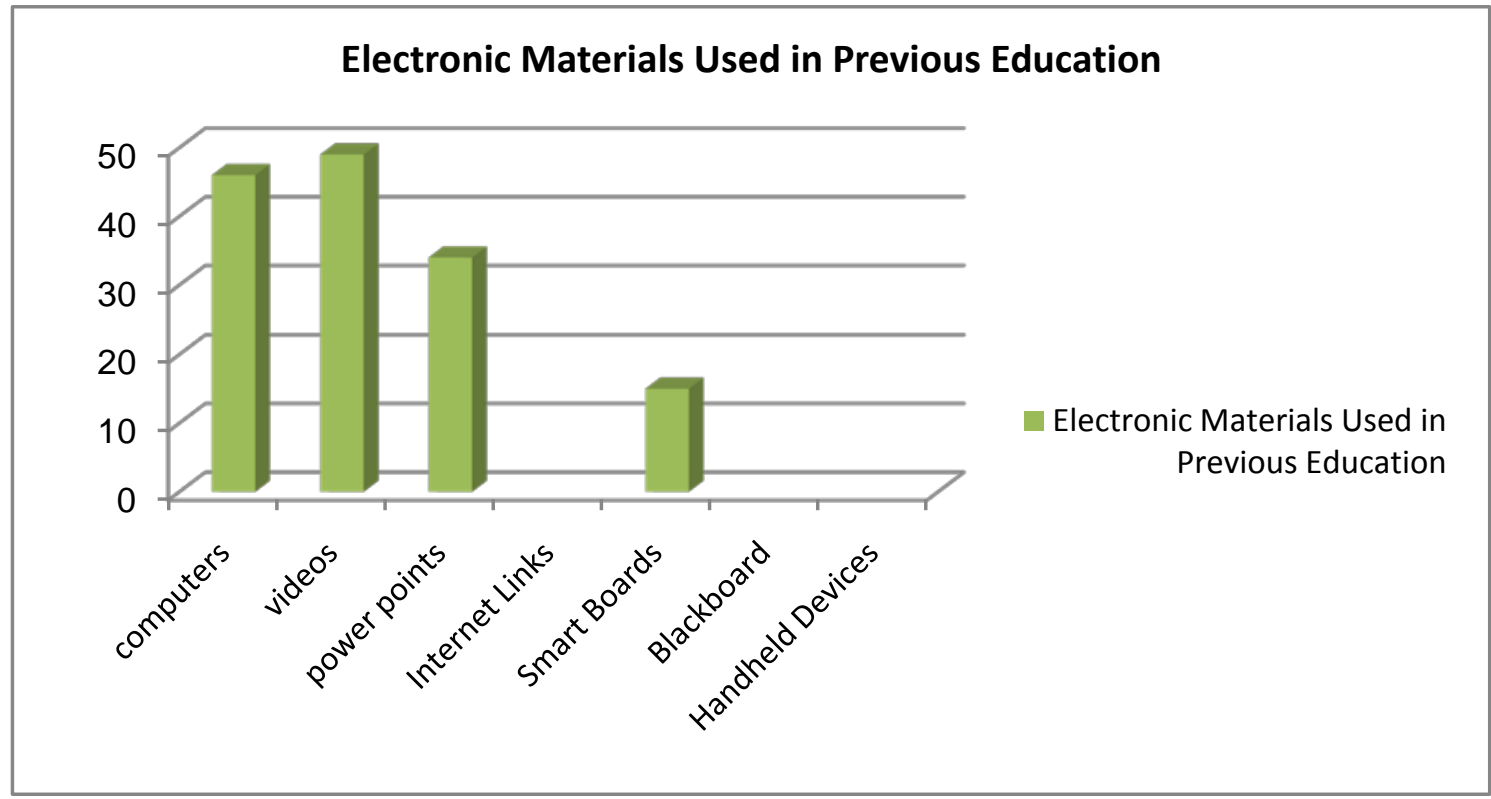

Figure 3. Electronic Materials Used in Previous Education

The students reported using all of the electronic materials included in the survey in their classrooms. Thirty-five of the students reported using computers, twenty-nine said they used videos, forty-seven students said they used power points, twenty-one students said they used Internet links, fifteen students said they used Smart Boards, fifty students said they use Blackboard, and fifty students said they used handheld devices.

When asked about their satisfaction with their use of technology in their classes, forty of the students said they were very satisfied, five students said they were somewhat satisfied, three students said they were neutral, and two students said they were somewhat dissatisfied. None of the students reported being very dissatisfied with the technology used in their classrooms (See Figure 2).

When asked which electronic materials were the most helpful in their current classes, computers were reported to be the most helpful by forty-eight students, followed by
Blackboard which was said to be most helpful by forty-four students. Thirty one students reported that power point was the most helpful. Twenty students said that they felt that videos were most helpful. Eleven students found videos most helpful. Eight students reported that Smart Boards were the most helpful and two students reported that handheld devices were the most helpful. None of the students said that Internet links or handheld devices were the most helpful (see Figure 3).

Nearly all of the students reported having used technology in the classroom prior to coming to the United States. Forty-six students reported using computers in their previous classrooms, forty-nine reported using videos, thirty-four students reported using Power Point, no students reported using Internet links, fifteen students reported using handheld devices, no students reported using Smart Boards, and no students reported using Blackboard (see Figure 3). 


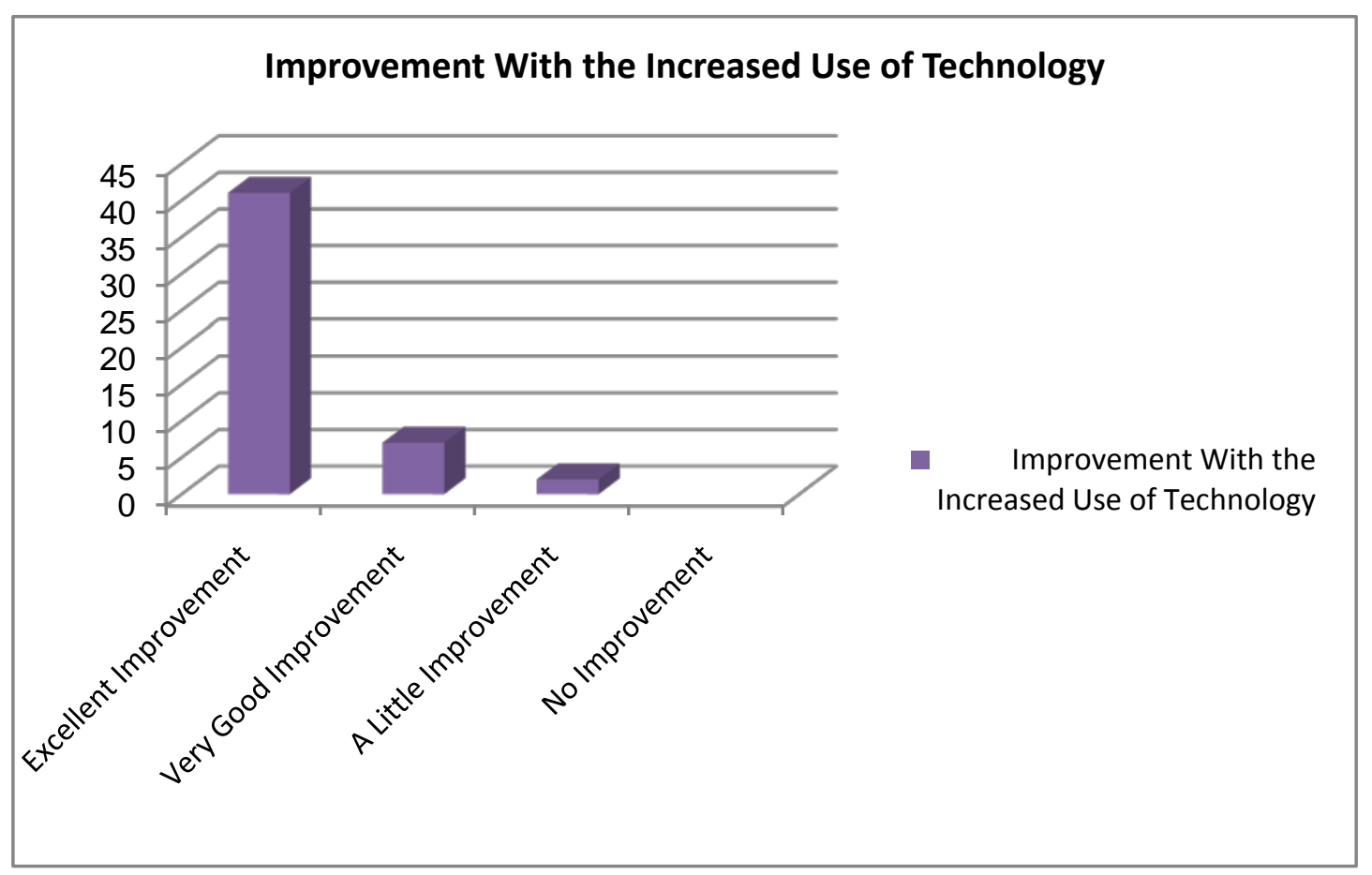

Figure 4. Improvement with the Increased Use of Technology

When the students reported the impact of their educational experiences with technology, forty-one students reported excellent improvement, seven students reported very good improvement, and two students reported a little improvement. None of the students reported having experienced no improvement (see Figure 4).

\section{Discussion}

This research has provided support for my hypothesis, which stated that when Saudi students are given the opportunity to use advanced educational technologies in their classes, then their perceptions of the quality of education they receive and their ability to obtain knowledge will increase as compared to previous education with older, less advanced educational technologies. The results of this research showed that the students who studied in the United States and used technology that they did have access to in their previous classrooms, found their use of these technologies to be beneficial to their education. For example, of the students who used technology in their classrooms in the United States, every single student reported some kind of improvement in their learning as a result of these technologies. As demonstrated in Figure 3, forty-one of the fifty students who took this survey reported excellent improvement in their studies due to the technology they are using, seven students reported very good improvement, and two students reported a little improvement. This result shows that my hypothesis was correct and that the use of technology in the classroom is beneficial to the learning environment, and the learning, of the students.

I find it very interesting that some of the students reported to have little improvement to their education through the use of technology and I have to wonder why this might be the case. As the survey was conducted anonymously, I cannot ask the people who reported these results what their reason was, so I can only speculate. My suspicion is that these students prefer another type of learning material such as text books or lectures over materials such as computers. These people might have a preference for learning through listening rather than learning through reading. Additionally, the cost of the electronic materials might have had an impact on whether the student found it beneficial to them or not. Some students cannot afford electronic learning tools, and so these students would not be able to experience the benefits of these learning materials. Because the income of the student was not asked, this type of theory cannot be proven. Another interesting find was that people with children were more likely to use technology at home than those who did not have children. I speculate that the reason for this is because children love to use technology, and so the people who have children are more likely to use more technology than those without children to consider.

The survey that was conducted for this research study was conducted on a group of my peers, and as such, the students had no fear of giving wrong answers. Additionally, the survey was not graded, which also gave the students the freedom to answer as honestly as possible. The survey was conducted only one time and it did not take a considerable amount of time to collect the results, so there was no threat of the maturity or the learning level of the students changing at all. The students were not treated any differently based on their answers. These factors ensured that there would be no significant threats to the internal validity of the research study that was conducted.

There were a few factors that impacted the validity of the study that was conducted. For example, because there was not an equal number of males and females who took this study, it can be assumed that the results might not be as accurate as if the gender of the students had been 
divided equally. Additionally, household income was not taken into consideration and, as previously mentioned, this factor could have had an impact on the final outcome of some of the surveys. However, while these variances occurred within this study, they are, in fact, minimal and as such, there is no data that shows any significant anomalies that would compromise the overall credibility of this study.

\section{Conclusion}

To conclude this research, this study has shown that the use of technology as an educational tool is very beneficial as perceived by the student. Through research studies similar to this one, educational facilities can come to the realization of what specific technologies are the most beneficial in the classroom and which ones are not as helpful to the students. They can use this information to determine what technologies are worth investing in and what technologies would be better left out of the classroom. This type of information can also be used to help educators understand the differences in education between two countries (in this case Saudi Arabia and the United States). Furthermore, this type of research study can help educators understand the influence of different factors on a student's preference of learning devices, such as whether being a certain age gives the students a preference of one type of technology over another.

Although this study did contain some limitations, the overall outcome of this research study was conclusive. The limitations of this study included that there was no identification of incomes, that the study was only conducted at one small Midwestern university, that the study was concluded only one time, and that the study was not concluded over a period of time. Furthermore, there was no consideration taken for things like visual or auditory impairment which could have had a major impact on the technological preference of the student. Each of these things could have been a limiting factor for the results of the study.

\section{References}

[1] Bhat., S. (2012). USES AND ADVANTAGES OF MODERN TECHNOLOGY IN PHYSICAL EDUCATION. Indian Streams Research Journal, 2(3), 69-71.

[2] Hew, K., \& Cheung, W. (2013). Use of Web 2.0 Technologies in K-12 and Higher Education: The Search for Evidence-Based Practice. Educational Research Review, 947-64.
[3] Lewis, C., Fretwell, C., Ryan, J., \& Parham, J. (2013). Faculty Use of Established and Emerging Technologies in Higher Education: A Unified Theory of Acceptance and Use of Technology Perspective. International Journal Of Higher Education, 2(2), 22-34.

[4] Zin, M., Latif, M. S. A., Bhari, A., Sulaiman, R., Rahman, A. A., Mahdi, A. F., \& Jamain, M. S. (2012). Education quality enhancement via multimedia technology. Asian Social Science, 8(10), 103-107.

[5] Moller, Foshay, and Huett(2008). The Evolution of Distance Education: Implications for Instructional Design on the Potential of the Web. Techtrends: Linking Research \& Practice To Improve Learning, 52(5), 63-67.

[6] Shaltry, C., Henriksen, D., Wu, M., \& Dickson, W. (2013). Situated Learning with Online Portfolios, Classroom Websites and Facebook. Techtrends: Linking Research And Practice To Improve Learning, 57(3), 20-25.

[7] Junco, R. (2012). The relationship between frequency of Facebook use, participation in Facebook activities, and student engagement. Computers and Education, 58 (1), 162-171

[8] Little-Wiles, J., \& Naimi, L. (2011). Student Perceptions of and Experiences in Using The Blackboard Learning Management System. Global Education Journal, (4), 147-155.

[9] Okoro, E. (2012). Integrating Social Media Technologies in Higher Education: Costs-Benefits Analysis. Journal of International Education Research, 8(3), 255-262.

[10] Bradford1, P., Porciello, M., Balkon, N. and Backus, D. (2007). The Blackboard Learning System. The Journal of Educational Technology System. 35:301-314.

[11] Alexander, P. A., Schallert, D. L., \& Reynolds, R. E. (2009). What is learning anyway? A topographical perspective considered. Educational Psychologist, 44176-192.

[12] Manuguerra, M., \& Petocz, P. (2011). Promoting student engagement by integrating new technology into tertiary education: The role of the iPad. Asian Social Science, 7(11), 61-65.

[13] Mouyabi, J. (2011). Higher education in the wake of new ICT: Reaping benefits or creating more problems through elearning?.South African Journal Of Higher Education, 25(6), 1178-1189

[14] Ekta Jain, C. (2011). Enhancing Quality and Accessibility of Higher Education through Use of Technology. Indian Journal Of Higher Education, 2(2), 105-111.

[15] Burns, M. (2013). Success, Failure or no Significant Difference: Charting a Course for Successful Educational Technology Integration. International Journal Of Emerging Technologies In Learning, 8(1), 38-45.

[16] Leer, R., \& Ivanov, S. (2013). RETHINKING THE FUTURE OF LEARNING: THE POSSIBILITIES AND LIMITATIONS OF TECHNOLOGY IN EDUCATION IN THE 21ST CENTURY. International Journal Of Organizational Innovation, 5(4), 14-20.

[17] Ravasco, G. (2012). Technology-Aided Cheating in Open and Distance e-Learning. Asian Journal Of Distance Education,10(2), 71-77.

[18] Tomar, D. (2012). The shadow scholar: how I made a living helping college kids cheat / Dave Tomar. New York: Bloomsbury, 2012.

[19] Russell James L. Hill. (2001) Action-monitoring and Intention Reporting in Children with Autism vol42 No3 pp317.

[20] Buche, M. W., Davis, L. R., \& Vician, C. (2012). Does Technology Acceptance Affect E-learning in a Non-TechnologyIntensive Course? Journal Of Information Systems Education, 23(1), 41-50. 